\title{
Research Paper \\ The Effectiveness of Hope Therapy on Promoting Mental Health and Reducing Academic Burnout in High School Students at Risk for Academic Burn-out
}

\section{Mojtaba Mahdavi*1 ${ }^{* 1}$ Ahmad Behpajooh ${ }^{2}$, Saeed Hasanzadeh ${ }^{3}$, Seyed Saeed Sajadi Anari ${ }^{1}$}

1. Ph.D. Student of Psychology and Education of Exceptional Children, Faculty of Psychology and Educational Sciences, University of Tehran, Iran

2. Professor, Department of Psychology and Education of Exceptional Children, Faculty of Psychology and Educational Sciences, University of Tehran, Iran

3. Associate Professor, Department of Psychology and Education of Exceptional Children, Faculty of Psychology and Education, University of Tehran, Iran

Citation: Mahdavi M, Behpajooh A, Hasanzadeh S, Sajadi Anari SS. The effectiveness of hope therapy on promoting mental health and reducing academic burnout in high school students at risk for academic burn-out. Quarterly Journal of Child Mental Health. 2020; 7(1): 128140.

doihttp://dx.doi.org/10.29252/jcmh.7.1.12

\section{A R T I C L E I N F O}

\section{Keywords:}

Giftedness, mental health, academic burnout
Received: 24 May 2018 Accepted: 8 Nov 2018 Available: 20 Jun 2020

\section{A B S T R A C T}

Background and Purpose: In recent years, educators, researchers, and professionals have increasingly felt the need to pay attention to the mental health of gifted people; therefore, a movement has been formed for study and research in this field. In this regard, the present study was conducted to investigate the effect of hope therapy on improving mental health and reducing academic burnout of gifted students.

Method: The research method was semi-experimental and pre-test-post-test-follow-up with the control group. The statistical population included all the gifted high school students in Sabzevar city in the academic year of 2015-2016, who were exposed to academic burnout. From this statistical population, 30 students were selected by convenient sampling method and randomly divided into two experimental and control groups (15 students in each group). Data were collected using the General Health Questionnaire (Goldberg and Hiller, 1979) and the Maslach Burnout Inventory (Schaufeli, Bakker, Hoogduin, Schaap, \& Kladler, 2001). The experimental group received hope therapy training for 8 sessions and the control group did not receive any intervention. After the sessions, both groups were tested again using the mentioned questionnaires and at the end the obtained data were analyzed using repeated measurement analysis.

Results: Results showed that hope therapy significantly enhances dimensions of mental health and decreases dimensions of academic burnout $(\mathrm{p}<0.05)$.

Conclusions: Based on the findings of this study, it can be concluded that the optimistic program has improved mental health of gifted students by creating realistic goals and reducing the level of frustration in them.

\footnotetext{
* Corresponding author: Mojtaba Mahdavi, Ph.D. Student of Psychology and Education of Exceptional Children, Faculty of Psychology and Educational Sciences, University of Tehran, Iran.

E-mail addresses: Mojtabamhd22@gmail.com
} 


\section{اثربخشى آموزش برنامهُ اميدبخشى بر ارتقاى سلامت روانى و كاهش فرسودكى تحصيلى دانش آموزان تيزهوش}

\section{مجتبى مهدوى *'، احمد به يزوهـ"، سعيد حسنزاده"، سيد سعيد سجادى انارى'}

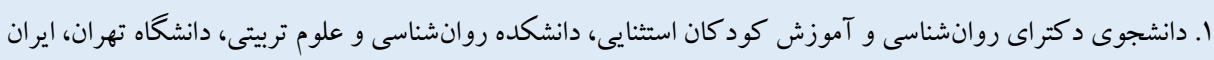

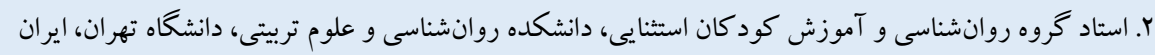

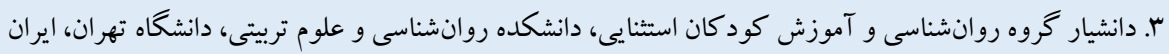
مشخصات مقاله

زمينه و هدف: در سالهاى اخير، مريان، يزوهشخران، و متخصصان، بيشازيش، ضرورت توجه به سلامت روان افراد تيزهوش را احساس

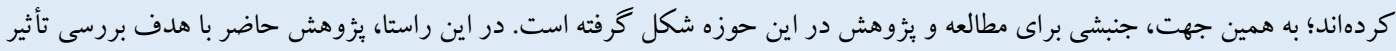
آموزش برنامة اميدبخشى بر ارتقاى سلامت روانى و كاهش فرسودگ تحى تحصيلى دانش آموزان تيزهوش انجام شد.

جكيله

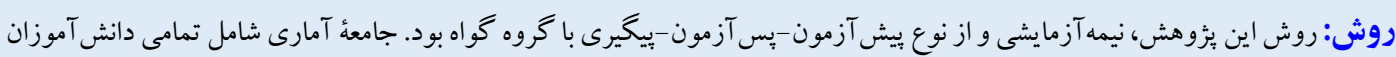

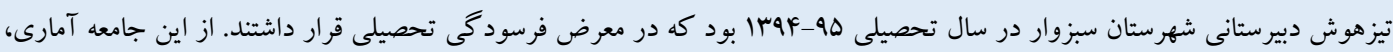

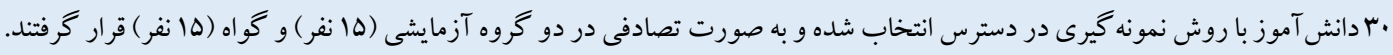

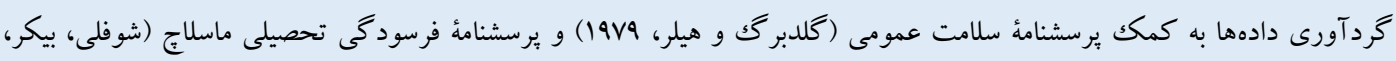

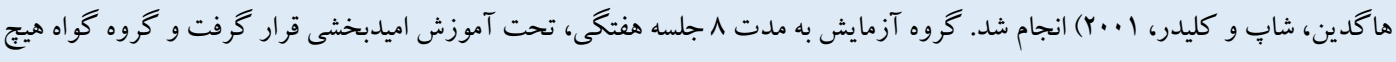

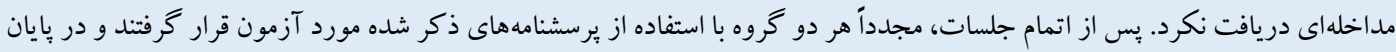

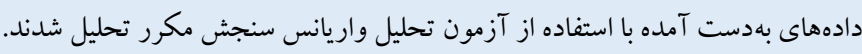

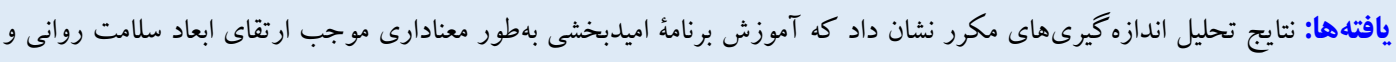

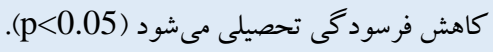

نتيجه كيرى: بر اساس يافتهاى بهدست آمده در اين مطالعه مى توان نتيجه گيرى كرد كه برنامه اميدبخشى با ايجاد اهداف واقع بينانه و كاهش

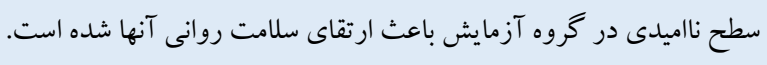

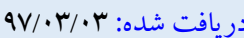

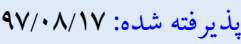

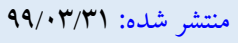

* نويسنده مسئول: مجتبى مهدوى، دانشجوى دكتراى روانشناسى و آموزش كود كان استثنايى، دانشكده روانشناسى و علوم تربيتى، دانشگاه تهران، ايران.

رايانامه: Mojtabamhd22@gmail.com

تلفن تماس: 
كو دكان تيزهوش "اسـت كه بيان مى كند: افراد تيزهوش كسـانى هستـند

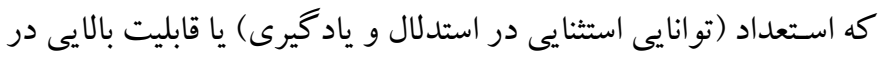

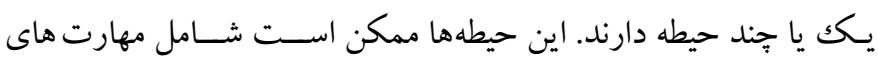

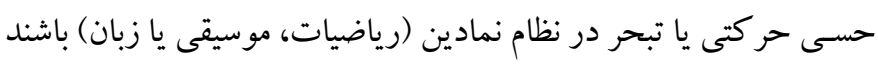

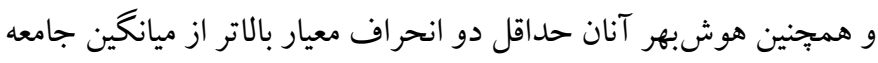

(9) (9) (9)

در سـالهاى اخير، مربيان، بزروهشــران و افراد جامعه، بيشازيش،

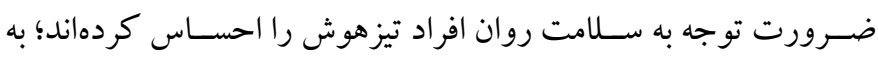

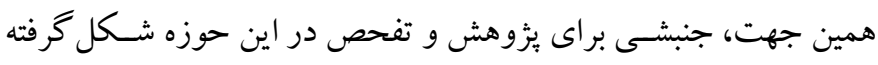

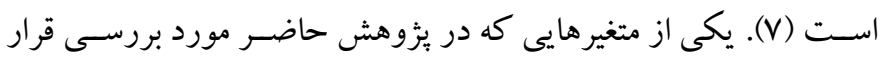

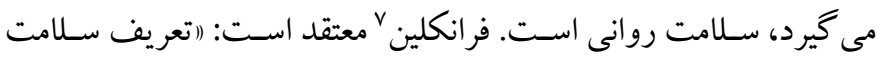
روانى همواره در حال تغيير بوده است، بهطورى كه تعريف مورد قبول در فر مردين

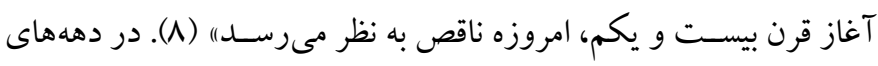

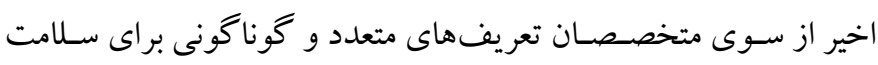

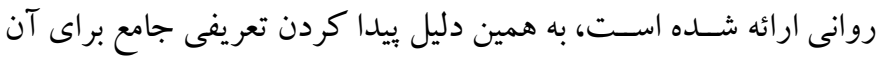

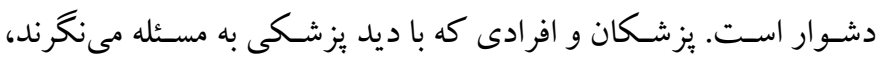

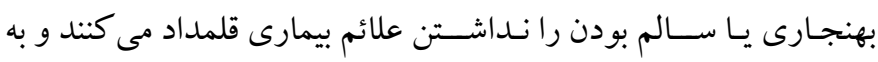

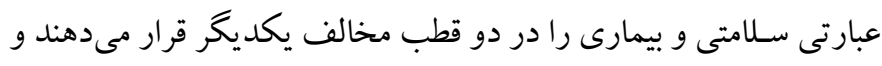

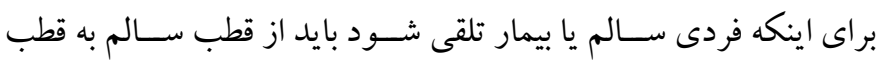

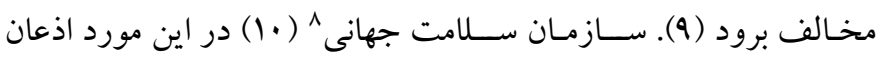

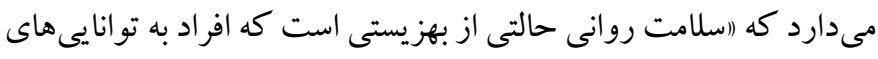

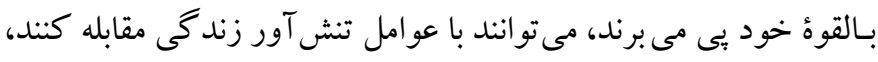

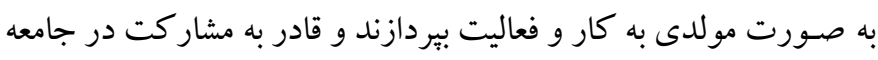
هستيند. سلامت روانى شامل بهزيستى جسمانى، روانى و اجتماعى است و صرفاً به فقدان بيمارى اشاره نداردا). برخى از دانش آموزان تيزهوش، از نظر تحصسيلى ضعيف هستند و به

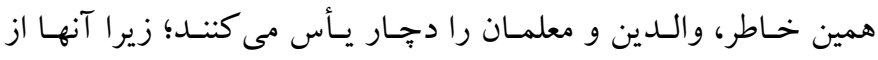

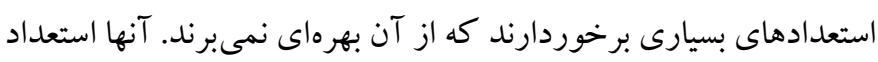

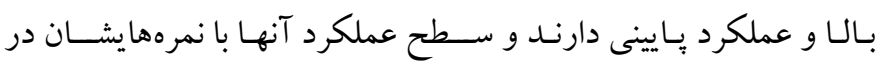

5. Creativity-intelligence-wisdom

6. National Association for Gifted Children

7. Franklin

8. World Health Organization (WHO)
مقلدمه

امروزه علم روانشناسى و بهره گيرى از فنون آن نقش مهمى را در مطالعه

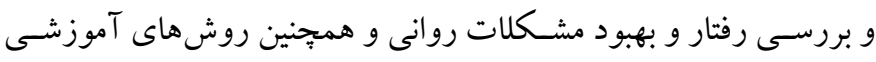

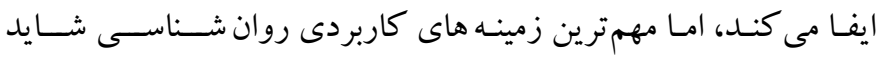
حيطههايى باشند كه با آموزش و يرورش مرتبط اند (1). تمام كود كان از

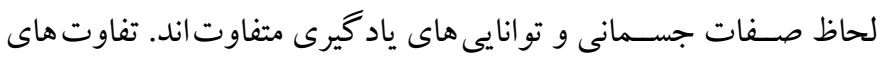

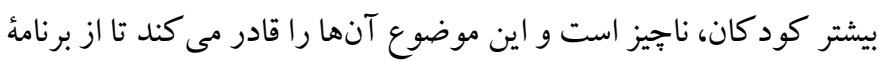
آموزش عمومى استفاده كنند. صسفات جسـمانى يا توانايىهاى ياد خيرى

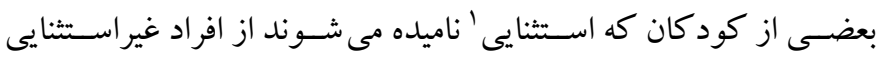

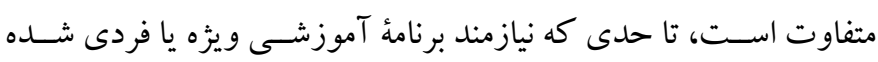

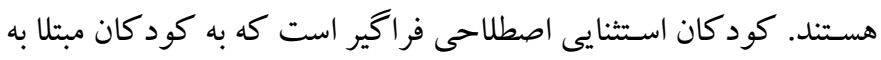

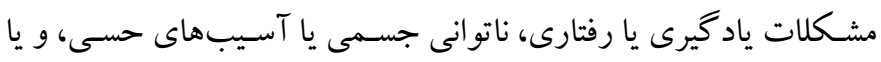

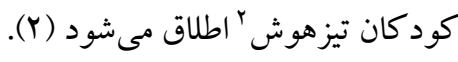
افراد تيزهوش كسـانى هســتند كه از لحاظ ظاهرى تفاوت جندانى با في

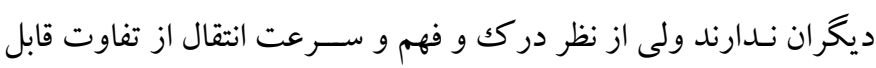

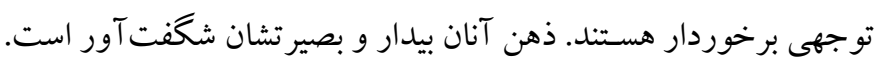

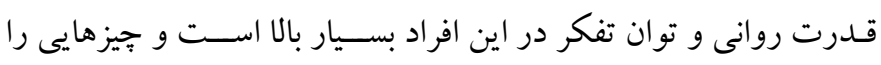

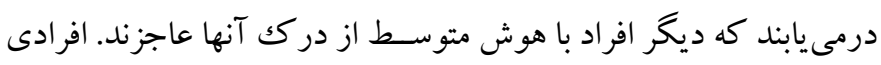
كه از نظر جامعه تيزهوش محسوب مى شوند، به طور معمول برجسب هاى مختلفى براى آنها به كار مىرود (r). تعريف هاى متعددى از تيزهوشى ارائه شده است. رنزولى (F) دو نوع

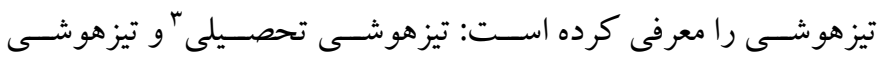

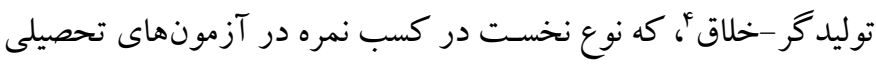

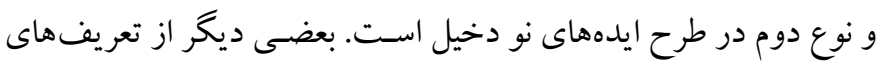

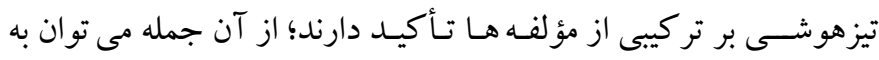

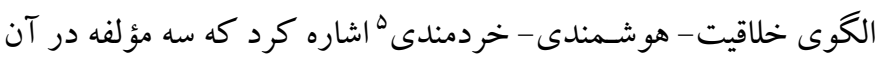
مورد تو جه اسـت: هوشـمندى، خلاقيت، و خردمندى. بر اين اسـاس در

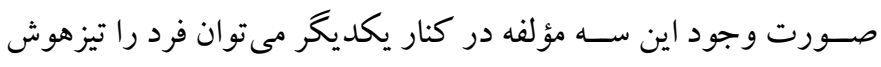

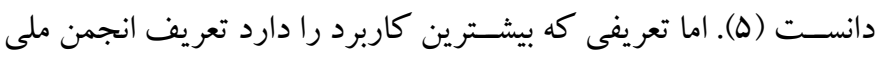

1. Exceptional children

2. Gifted children

3. Schoolhouse giftedness

4. Creative-productive giftedness 
دانش آموزان و دانشـجويان به ارمغان آورد. شــاختدرمانى براى درمان

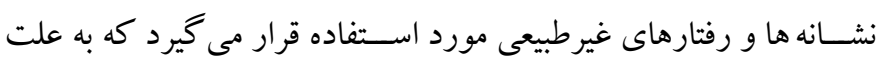

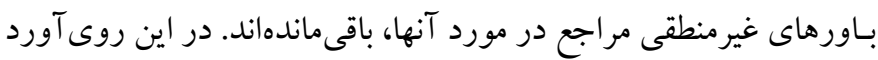

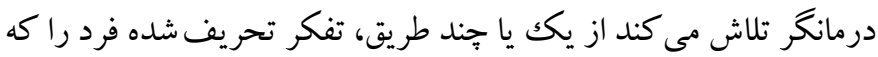
مشـصهُ مشكلات است تغيير دهل. همجنين شناخت درمانى بر اين نظريه

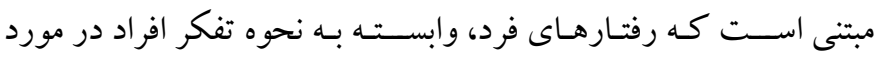
خودشان و نقششان در دنيا است و رفتارهاى غير انطباقى مى تواند ناشى از رهاز

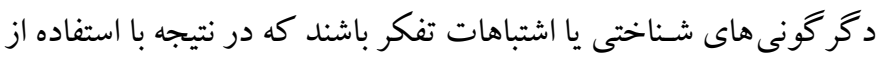

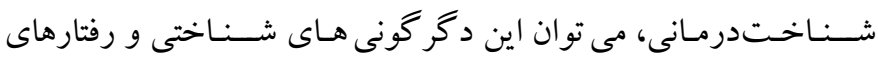
خودشكنانه ناشى از آنها را اصلاح كرد (ه) (1).

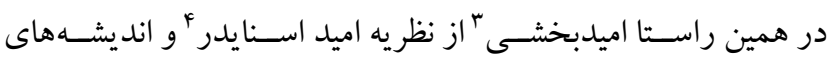

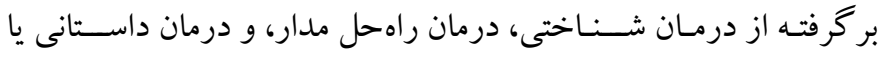

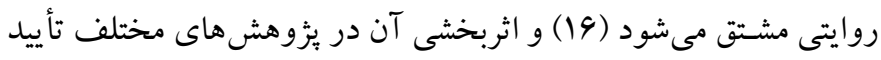

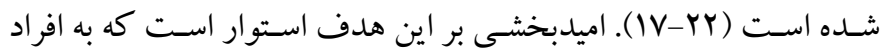

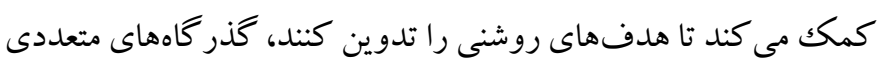

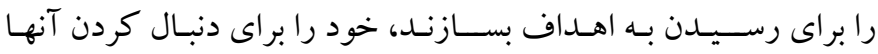

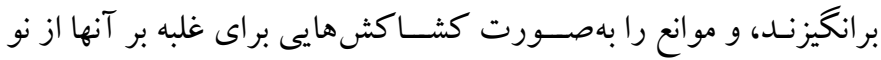

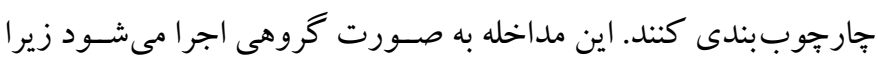

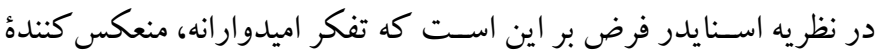
يك فرايند تبادلى است (r) براى اينكه نوجوانان و جوانان از شــخصـيت مســقتل و متعادلى كه

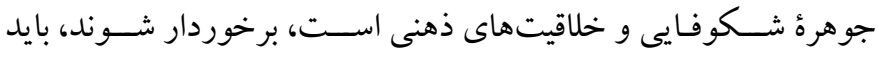

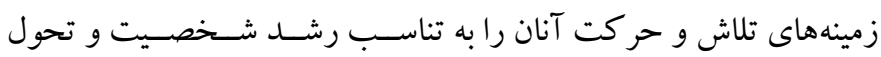

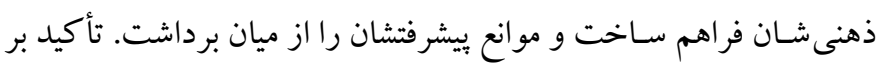

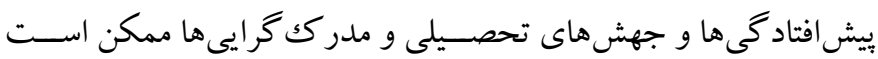

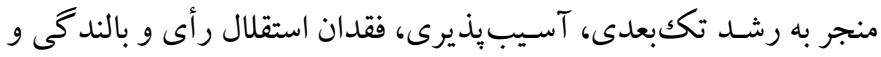

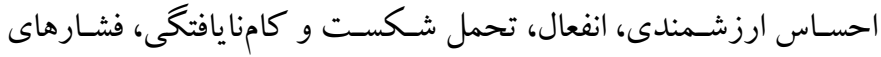

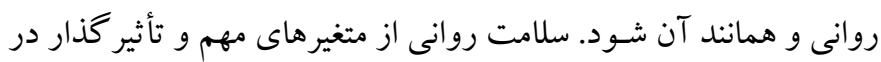

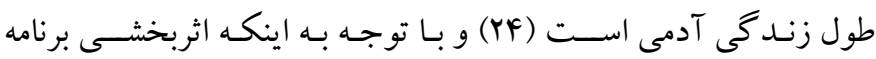
اميدبخشى بر سلامت روانى در مطالعات متعدد تأييد شده است و اميد از از رونس
آزمونهاى هوش و اسـتعداد، هماهنك نيست. در مطالعهاى طولى كه بر

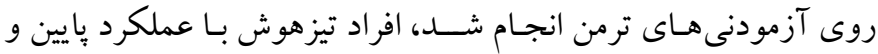

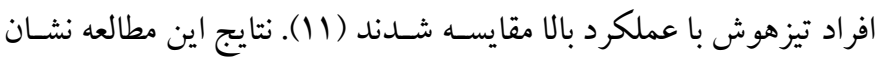
داد كه افراد گروه نخست در مقايسه با گروه دوم، احساس كهترى بيشتر،

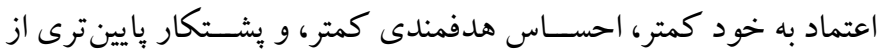
خود نشان مى دادند. دلايل متنوعى براى عملكرد بايين افراد تيزهوش وجود دارد. بسيارى

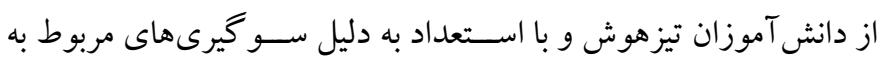
روش شناسايى، به موقع شناسايى نمىشوند و فرصت هاى بيشرفت از آنها

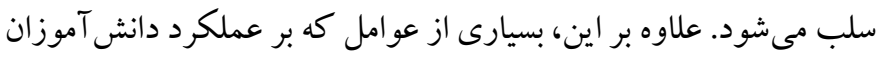

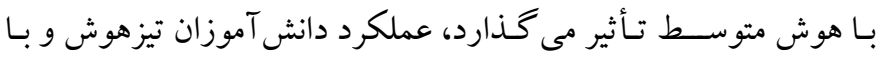

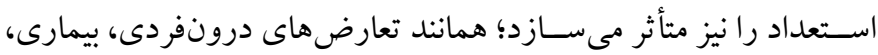
تعارض هاى خانو ادگىى، و محيط نامساعد. برنامه هاى درسى نامناسب نيز

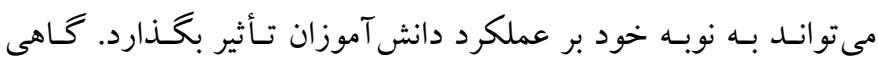

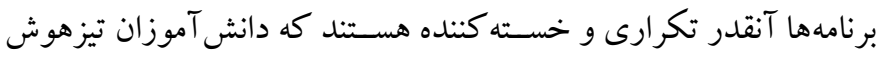

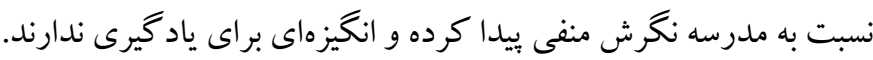

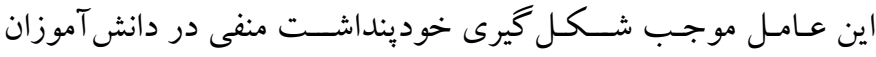

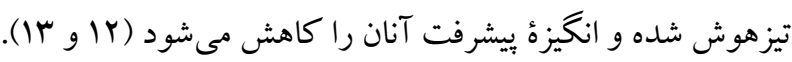
عوامل گوناكونى بر بيشـرفت و عملكرد تحصيلى دانش آموزان تأثير

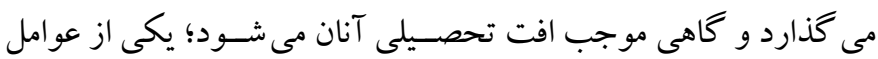

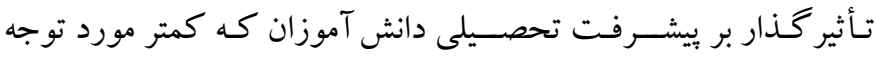

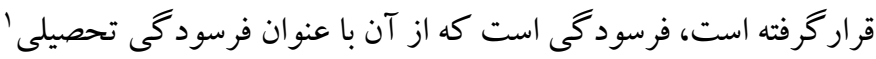

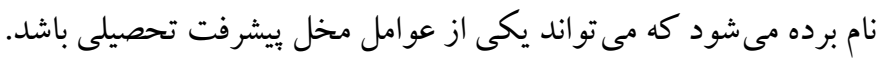

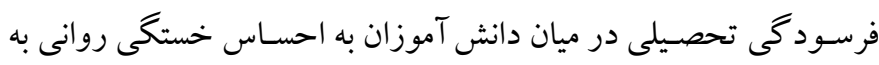

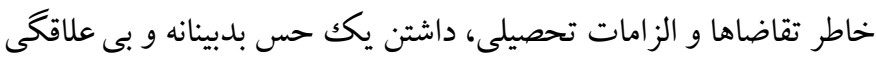

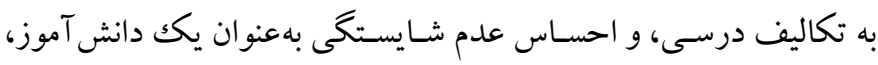

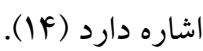
فنون مختلفى براى بهبود مشكلات تحصيلى و انكگيزشى دانش آموزان

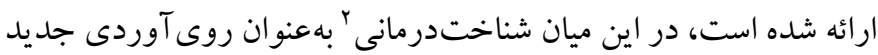
در روان شـناسى توانسته است توفيقات قابل توجهى را در بهبود مشكلات

1. Academic burnout

2. Cognitive therapy 
جسمانى يا بيمارى بزشـكى كه مانع شـر كت منظم در جلسـات مداخله

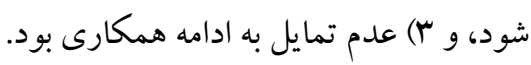

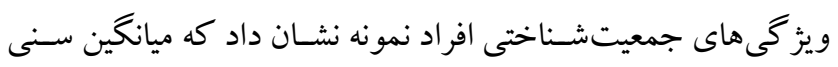

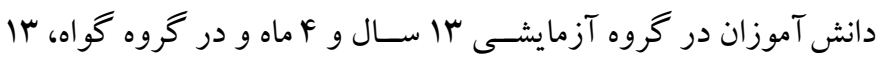

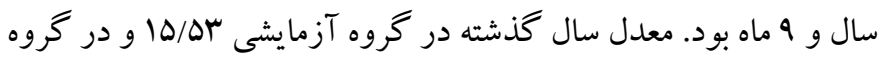

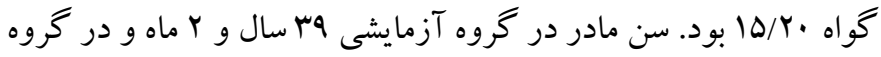

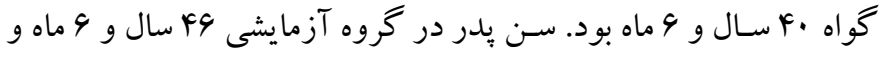

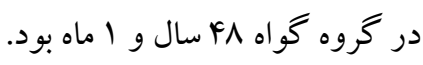

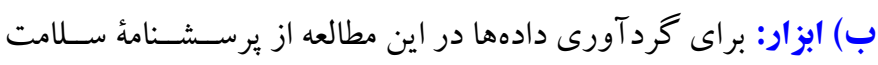

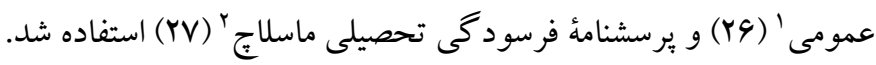

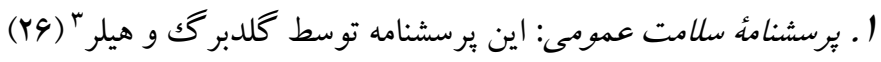

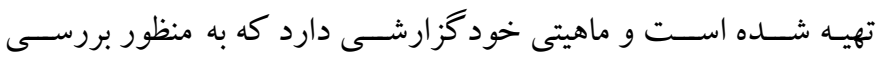

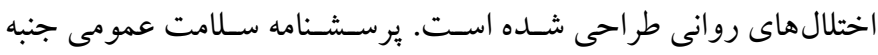
تشـيصى ندارد و تنها مى توان از آن براى تشخيص اوليه در شرايط حاد

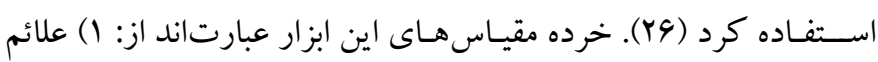

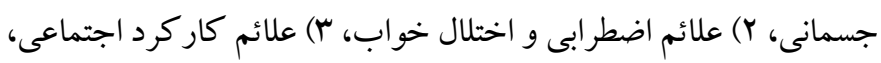

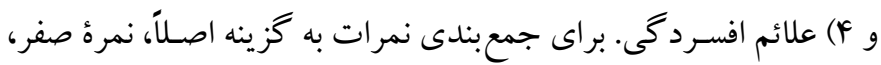

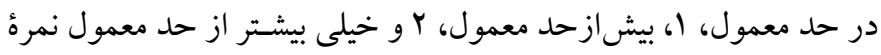

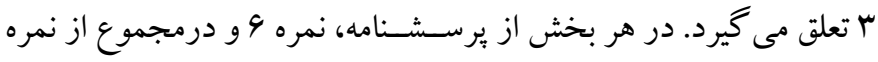

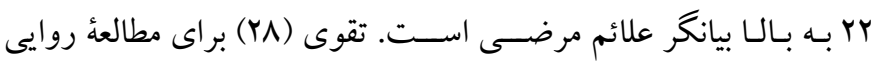

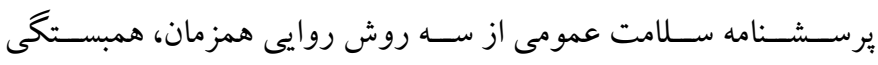
خردهآزمونهاى اين برسشنامه با نمره كل، و تحليل عوامل استفاده كرد.

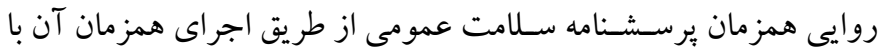

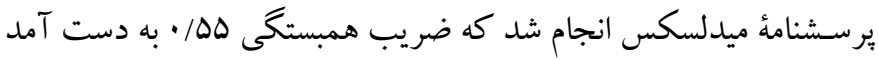
(YN) در حد رضـايت بخش و بين NY/ • IV • • متغير بود. نتيجة تحليل عوامل

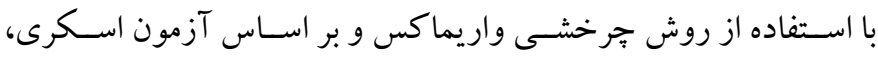

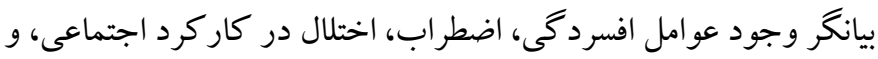

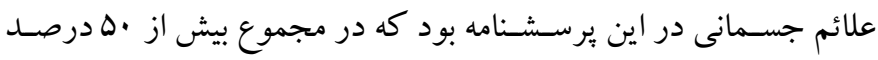
واريانس كل آزمون را تبيين مى كنند (YN).
يكك سو با شـاخص هاى آسيب روانى همبستـى منفى دارد و از سويى

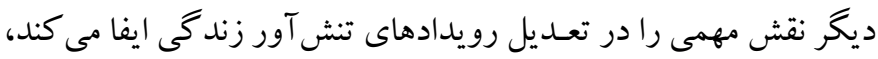
در نتيجه انجام مطالعات بيشتر در اين زمينه ضـرورى است. همجنين بايد

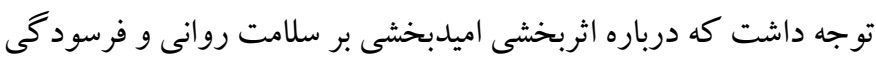

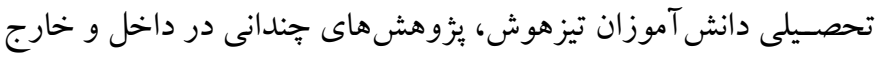

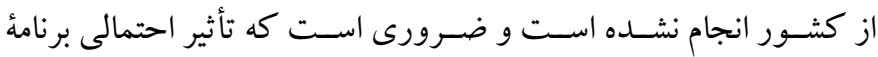

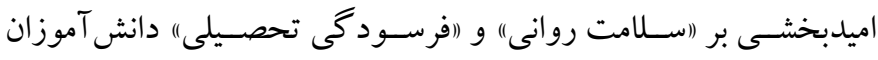
تيزهوش در معرض خطر فرسودگى تحصيلى مورد بررسى قرار گيرد.

روش

الف) طرح يثزوهش و شر كت كنند كان

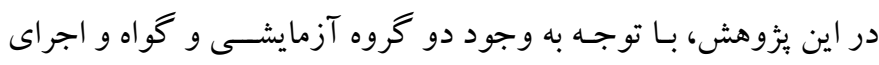

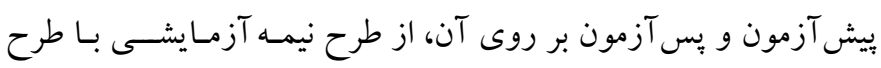

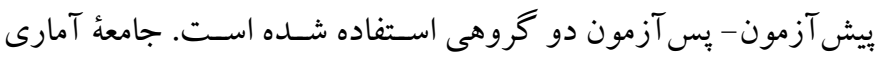

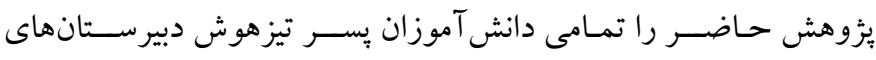

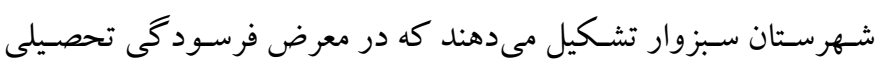
هستند و در سال تحصيلى

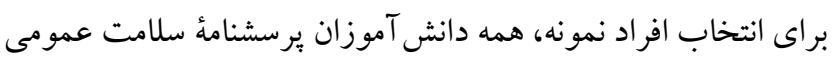

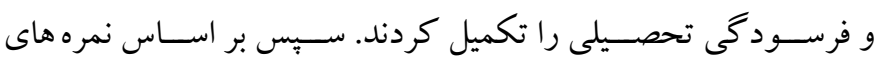

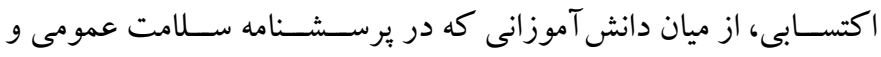

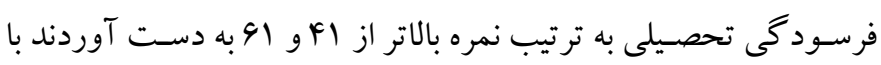

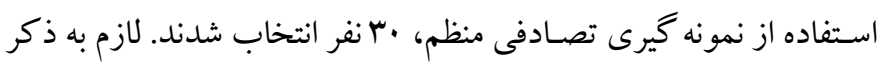

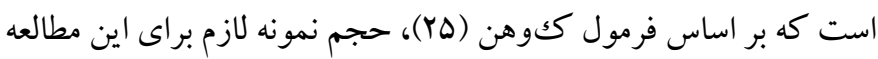

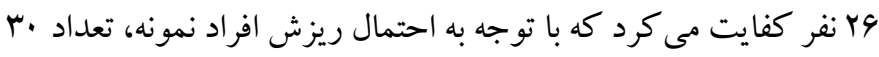
نفر انتخاب شـدند و به صسورت تصسادفى به دو گرووه آزمايشسى و كواه

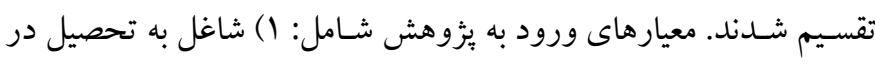

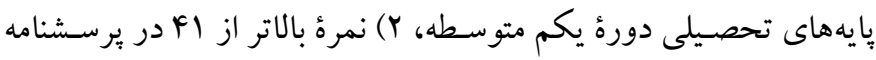

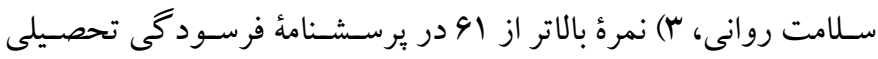

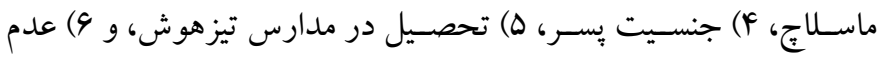

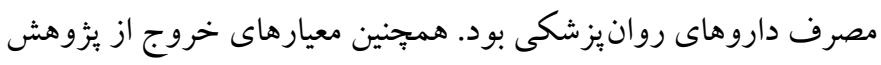

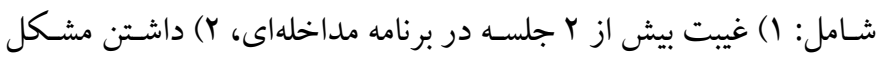


شـر كت كنند كان ابتدا با اصـول نظريه اميد آشــنا مىشوند و سبِ به آنها

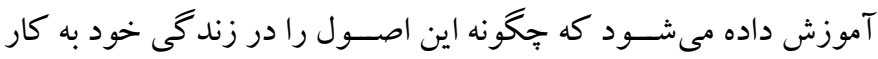

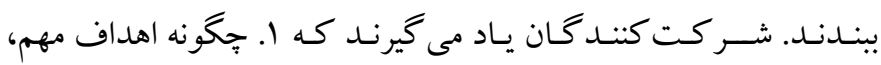

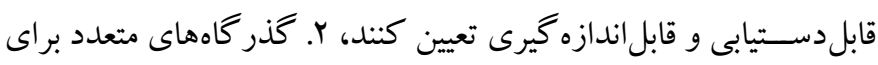

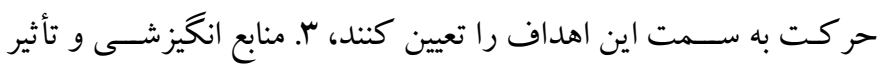

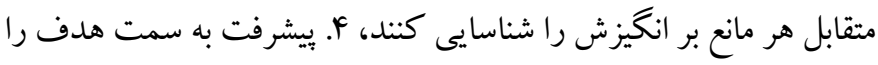

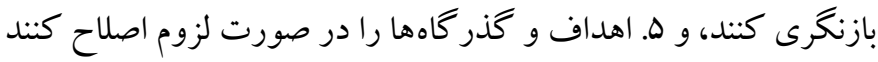

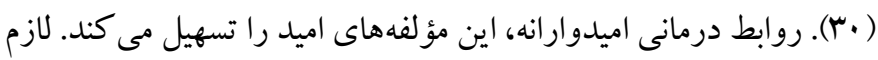
به ذكر است كه تغيير در اميد صرفاً در سطح رفتار نيست، كه طى درمان،

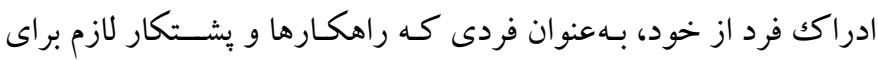
رسيدن به اهداف را دارد، تغيير مى يابد. در اين درمان، درمانكر به منظور بهر افزايش اميد به مداخله آموزشسى مى يردازد ( آس). خلاصسهُ جلســات اين برنامه در جدول اكزارش شده است.

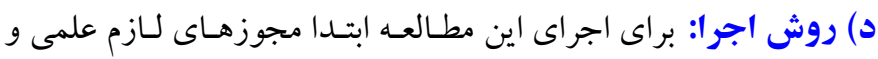

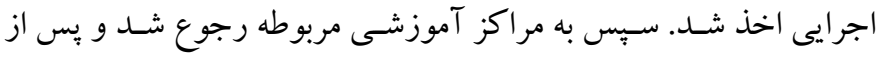

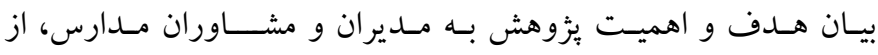
دانش آموزان خو استه شد تا در اين برنامه شركت كنند. رضايت آكًاهانه

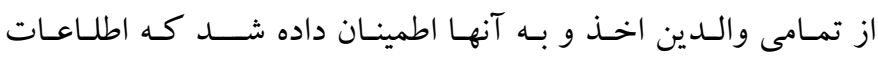

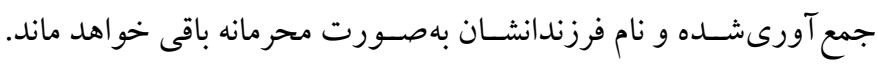

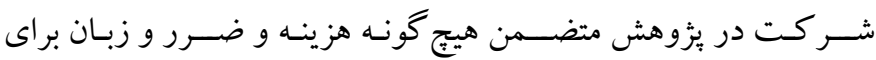

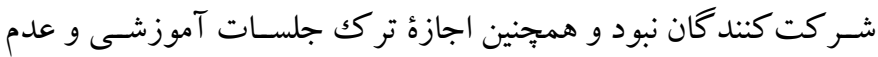

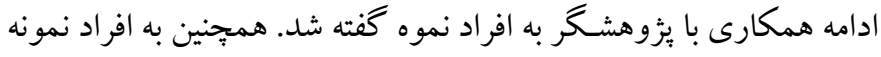
اطمينان داده شد كه به منظور حفظ اسرار شخصى و عدم تجاوز به حريم

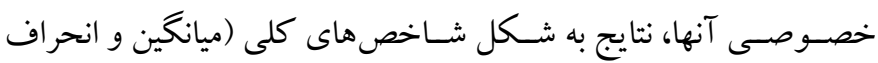

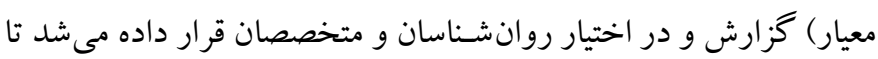

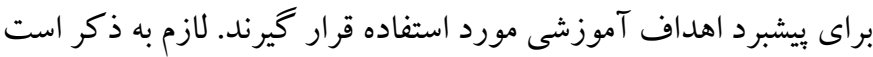
كـه بعـد از اجراى مطالعـه و جمع آورى دادهــاى للازم، تجزيه و تحليل

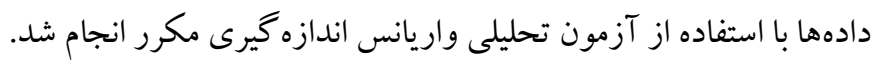

3. Academic efficacy

4. Utrecht work engagement student r. برسشـنامة فرسو كى تحصيلى ماسلاج: اين برسشنامه، اصلاحشده فرم

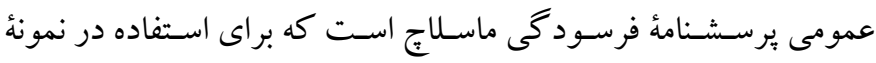

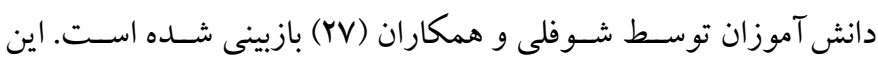

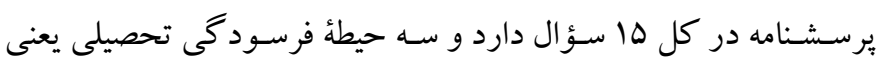

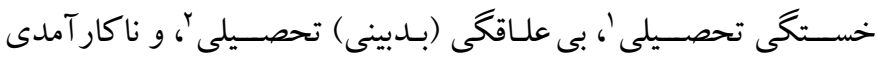

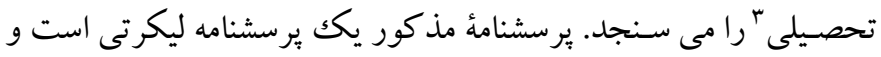

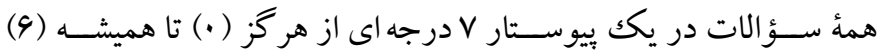
نمره گذارى مى شوند. نمرههاى بالا در خستخى عاطفى و شكى و بدبينى و

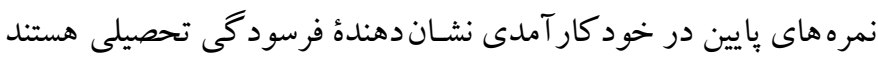

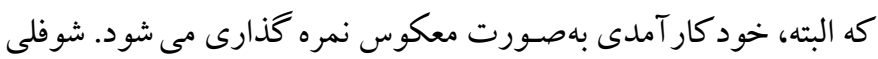

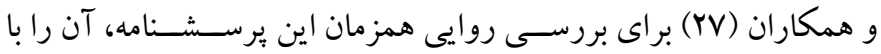

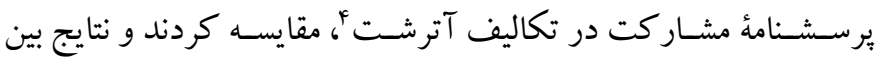

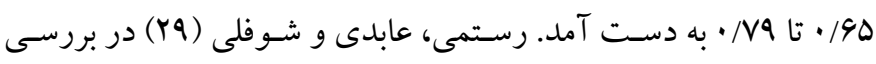

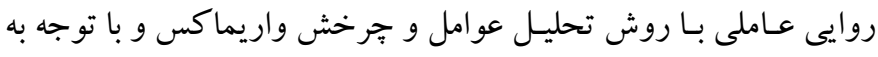

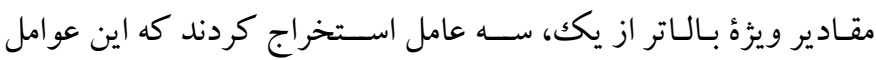
عبارتاند از: خستكىى عاطفى، شكى و بدبينى، و خود كار آمدى تحصيلى.

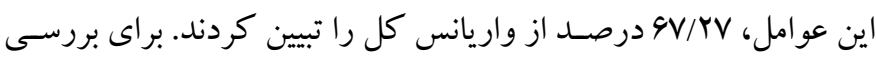

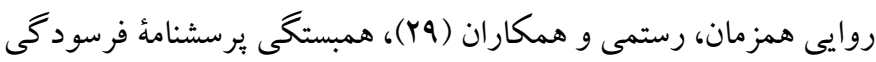

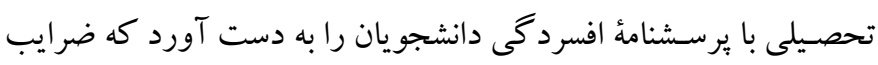

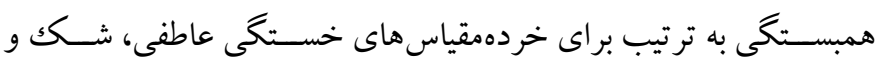

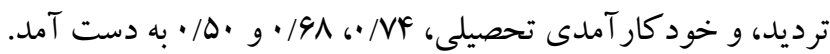
ج) بر نامه مداخلهاى تردئ

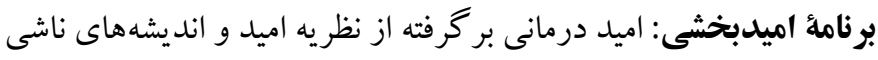

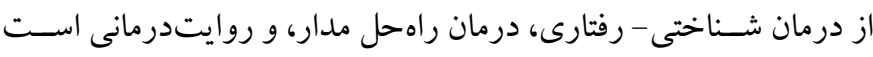

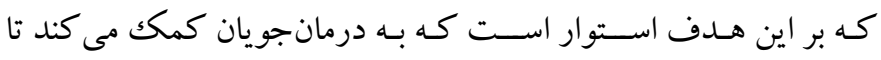

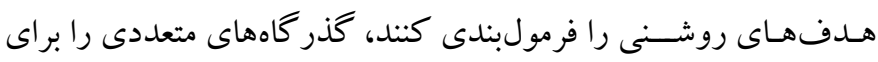

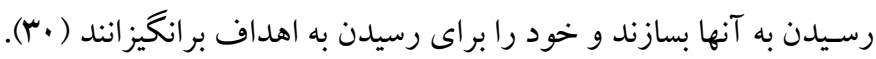

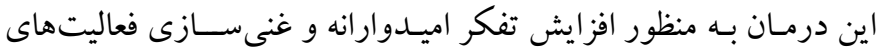

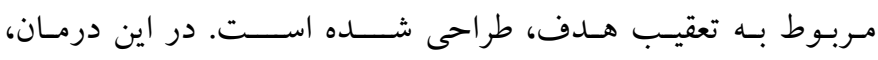

1. Academic exhaustion

2. Academic cynicism 
جدول ا: خلاصه جلسات مربوط به مداخله برنامه اميدبخشي

\begin{tabular}{|c|c|c|c|c|}
\hline \multicolumn{5}{|c|}{ عنوان مداخله: برنامة اميدبخشى } \\
\hline تكليف & روش تدريس / مدتزمان & محتوا & هدف & جلسه \\
\hline نوشتن داستان يا روايت زندگى به طور خلاصه & دانش آموز محور / ·4 دقيقه & 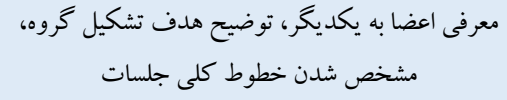 & آشنايى اعضا و رهنمودهايى براى مشاركت & 1 \\
\hline نوشتن اهداف خود در زندگى & دانش آموز محور / •1 دقيقه & مشخص نمودن سه مؤلفهُ اهداف، گذر گاهها، و نيروى عامل در هر كدام از داستانها & آشنايى با مؤلفهاى اهداف & $r$ \\
\hline بازبينى و بازنويسى اهداف بر اساس آموزش ها & دانش آموز محور / •^دقيقه & $\begin{array}{c}\text { آموزش ويثز گهاى اهداف مناسب در قالب كلمة } \\
\text { SMART }\end{array}$ & آشنايى با ويز گیىهاى اهداف & $r$ \\
\hline نوشتن تمام راههاى ممكن و كار آمد براى & دانش آموز محور / ·م دقيقه & 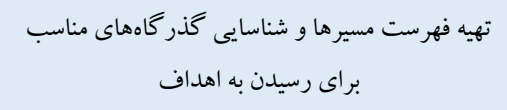 & آشنايى با نحوه نيل به اهداف & $F$ \\
\hline كَتن جملات خوش بينانه در طول روز & دانش آموز محور / •1 دقيقه & افزايش نيروى عامل با استفاده از تفكر مثبت و تكرار & افزايش نيروى عامل براى نيل به اهداف & $\Delta$ \\
\hline نوشتن فهرستى از موانع و خود گويىهاى منفى & دانش آموز محور / •1 دقيقه & 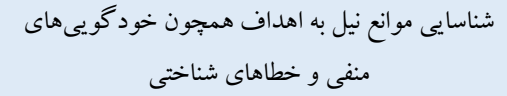 & شناسايى موانع نيل به اهداف & 9 \\
\hline نوشتن راههاى گوناگون رسيدن به اهداف & دانش آموز محور / ·^ دقيقه & 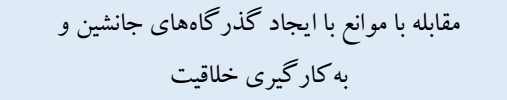 & آموزش مقابله با موانع & $V$ \\
\hline نوشتن اهداف خود و نتيجه گيرى نهايى & مستقيم / •1 دقيقه & بازنگرى نهايى جلسات و جمعبندى & جمعبندى و نتيجه گيرى & $\wedge$ \\
\hline
\end{tabular}

بودن توزيع متغيرهاى وابسته در گروههاى آزمايش و گو اه در جدول r

يافته ها ارائه شده است. ميانگين و انحراف استاندارد نمرات بِيش آزمون، بس آزمون، و بيگيرى

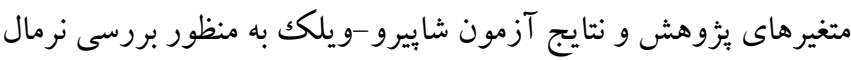

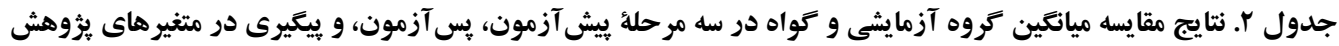

\begin{tabular}{|c|c|c|c|c|c|c|}
\hline سطح معنى دارى & خطاى استاندارد بر آورد & تفاوت ميانگين & ميانكين تواه & ميانتين آزمايش & مرحله & متغير \\
\hline$\cdot / 1 \cdot 9$ & $\cdot / \Delta F$ & $\cdot / \mu$ & $11 / 49$ & $11 / 4$ & ي بيش آزمون & \multirow{3}{*}{ نشانه هاى جسمانى } \\
\hline$\% r$ & $\cdot / \mathrm{V} 9$ & r & $11 / \Delta r$ & N/Dr & 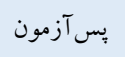 & \\
\hline$\% \cdots$ & $\cdot / N$ & $-f$ & $11 / r$. & $V / r$. & ييگيرى & \\
\hline.$/ 94 \Delta$ & $\cdot / \wedge$ & .1 .9 & $11 / .9$ & $11 / 1 r$ & ي يِش آزمون & \multirow{3}{*}{ نشانهاى اضطراب } \\
\hline.$/ .14$ & $\cdot / N r$ & $-r / \cdot 9$ & $11 / \pi$ & $9 / Y 9$ & يس آزمون & \\
\hline$\cdot \ldots$ & .194 & $-r / .9$ & $11 / 1 \pi$ & $\Lambda / \cdot 9$ & ييخيرى & \\
\hline$\cdot / / r$. & $\cdot \pi r$ & $-\cdot / \Delta r$ & ir & $11 / 49$ & ي بيش آزمون & \multirow{3}{*}{ كار كرد اجتماعى } \\
\hline •r & $\cdot / \mathrm{v}$ & $-r / \Delta r$ & $11 / 94$ & $9 / 4$. & يس آزمون & \\
\hline$\cdot / \cdots$ & .199 & r & $\mid r / .4$ & $\Lambda / V r$ & ييخيرى & \\
\hline$\cdot / N \cdot 4$ & $\cdot / 19$ & س & $1 \cdot / \Lambda$. & $11 / 1 r$ & ي ييش آزمون & \multirow{3}{*}{ شانههاى افسردگى } \\
\hline$\cdot / A \cdot \Lambda$ & $\cdot / A \cdot$ & $-\cdot / r$ & $11 / .9$ & $11 / \wedge 9$ & يس آزمون & \\
\hline . /9HA & . & .1 .9 & $1 \cdot / \wedge$ & $1 \cdot / \wedge 9$ & ييگيرى & \\
\hline .199. & 1/א & -.19 & re/or & $r \Delta / q T$ & ي ييش آزمون & \multirow{3}{*}{ خستخى عاطفى } \\
\hline$\% \cdots 1$ & 1/9. & $-\Delta / 94$ & $r q / 1 T$ & $r \cdot / r$. & ي يس آزمون & \\
\hline$\% \Delta$ & $r / r$. & $-V / Y^{4}$ & rq & IN/NT & ييخيرى & \\
\hline$\cdot / 1 \cdot 1$ & $\cdot / 19$ & $-1 / \Delta r$ & rq/A. & $r \Delta / Y G$ & ي ي يش آزمون & \multirow{2}{*}{ بىعلاقگى تحصيلى } \\
\hline$\% r$ & $1 / \pi r$ & $-\phi$ & re/r. & $r \mid / r$. & يس آزمون & \\
\hline
\end{tabular}




\begin{tabular}{|c|c|c|c|c|c|c|}
\hline$\cdot / \cdot 1$ & $1 / \pi r$ & $-0 / 94$ & $r q / Y r$ & $r \cdot / \Delta r$ & ييخيرى & \\
\hline - /VaF & $1 / r \Delta$ & $-\cdot / \pi r$ & rq/Ar & rq/Dr & يِش آزمون & \\
\hline$\cdot / \cdots$ & $1 / F V$ & $-9 / 14$ & YV & IV/AS & يس آزمون & ناكار آمدى تحصيلى \\
\hline$\cdot / \cdots$ & $1 / H_{F}$ & -1 & $\mathrm{VV} / \cdot .4$ & $\mid \mathrm{V} / \cdot .4$ & ييخيرى & \\
\hline
\end{tabular}

مقيـاس فرســود كى تحصــيلى مـاســلـاج نيز نشــان از افزايش ميانخين خردهمقياس هاى فرسودگى تحصيلى است (جدول Y).

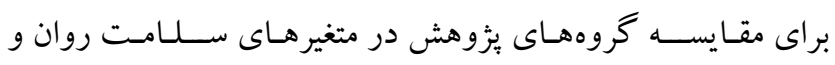
فرسـودگى تحصيلى از تحليل واريانس - طرح سنجش مكرر استفاده شد كه نتايج آن در جدول سارائه شده است.
يافته هاى توصيفى حاصل از گروه نمونه بر اساس مقياس هاى سلامت روانى نشــان مى دهنـــ كـه شــركت در كار كاه اميدبخشــى، در مرحله بس آزمون نسـبـت بـه مرحلـه بيش آزمون بـه افزايش ميـانكين در خرده مقياسهاى اين مقياس منجر شـده اسـت و اين ميزان در زمان بيكيرى نيز به قوت خود باقى بوده اسـت؛ اين در حالى اسـت كه دادههاى حاصل از

جدول r. نتايج آزمون تحليل واريانس براى بررسى تفاوت كروهها در متغيرهاى ثئوهش

\begin{tabular}{|c|c|c|c|c|c|c|}
\hline سطح معنى دارى & Tاره & ميانكين مجموع مجذورات & درجه آزادى & مجموع مجذورات & منابع تغيير ات & متغير \\
\hline זr•/. & $r / \cdot \Delta$ & IIV/AVA & 1 & IIV/AVA & كروهـا & \multirow{2}{*}{ نشانه هاى } \\
\hline$\cdot / \cdots$ & NF/KYq & GN/TGV & 1 & GN/TGV & & \\
\hline$\cdot 1 \cdots$ & $V q /|f|$ & $94 / .9 \mathrm{~V}$ & 1 & $94 / .9 \mathrm{~V}$ & تعامل مرا. & جسمانى \\
\hline.$/ \cdot F F$ & $F / 4 G$ & $G F / I V$ & 1 & $G F / I V$ & & \multirow{3}{*}{ نشانه هاى } \\
\hline$\cdot / \cdots$ & $r \cdot / \Delta \Delta$. & M/vo. & 1 & MT/VD. & & \\
\hline 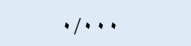 & טז/TM & rG/AIV & 1 & MG/AlV & تعامل مرا & \\
\hline$\cdot 1 \cdots 1$ & $\mid F / T$. & I. T/F.. & 1 & $1 \cdot r / F \ldots$ & & \\
\hline$\cdot / \cdots 1$ & $14 / 99$. & $\mathrm{r} 9 / 99 \mathrm{~V}$ & 1 & $\mathrm{r} 9 / 99 \mathrm{~V}$ & & \\
\hline$\cdot / \cdots$ & $19 / 194$ & $r q / F \ldots$ & 1 & $r q / F \ldots$ & 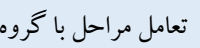 & \multirow{4}{*}{ نشانه هاى افسرد } \\
\hline$\cdot / a r \Delta$ & $\cdot / \cdot v$ & $\cdot / 1 \cdots$ & 1 & $\cdot / 1 \cdots$ & 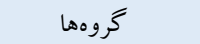 & \\
\hline$\cdot / \Delta \Delta r$ & $r / 10$ & $\cdot /$ YAV & 1 & $\cdot /$ TSV & & \\
\hline . / & $r / 10$ & $\cdot /$ TSV & 1 & $\cdot /$ TSV & تعامل مرا. & \\
\hline$\cdot / \cdot r$ & $1 \cdot / \mathrm{M}$ & FVG/I.. & 1 & FV9/1... & & \multirow{3}{*}{ ستخى عاطفى } \\
\hline$\cdot / \cdots$ & $M I / \cdot V$ & YYF/YGV & 1 & YYY/YGV & & \\
\hline$\cdot 1 \cdots$ & $r r / \cdot 9 \Delta$ & $199199 \mathrm{~V}$ & 1 & $199199 \mathrm{~V}$ & تعامل مرا- & \\
\hline$\cdot / \cdots$ & $r \cdot / r q$ & $M V Y / 1 .$. & 1 & $r V Y / 1 \ldots$ & 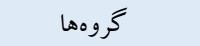 & \multirow{3}{*}{ تحصيلى علاقكى } \\
\hline$\cdot 1 \cdots$ & rV/DAG & $1.9199 \mathrm{~V}$ & 1 & $1.9199 \mathrm{~V}$ & & \\
\hline$\cdot / \cdots$ & $19 / 099$ & $9 F / .9 V$ & 1 & $94 / .9 \mathrm{~V}$ & تعامل مراحل با گروه & \\
\hline$\cdot / \cdots$ & rV/or & qFV/rVA & 1 & $\Lambda F V / r V \Lambda$ & 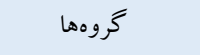 & \multirow{3}{*}{ تا كار آمدى } \\
\hline$\cdot / \cdots$ & $9 \Delta / \mu \cdot \Delta$ & $M r Y / \cdot I V$ & 1 & $M r Y / \cdot I V$ & مراحل & \\
\hline.$/ \cdots$ & $21 / .90$ & ro./FIV & 1 & $r \Delta \cdot / F I V$ & تعامل مراحل با گروه & \\
\hline
\end{tabular}

محاسـبهشده اثر خطى درون آزمودنى (Y (AF/Y براى نشانه هاى جسمانى،

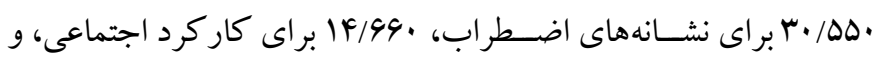

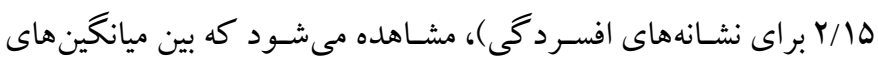
علائم جسـمانى، نشـانههاى اضـطراب، و كار كرد اجتماعى در سـه مرحله
نتايج تحليل دادهها درباره تأثير آموزش برنامهُ اميدبخشسى بر ارتقاى

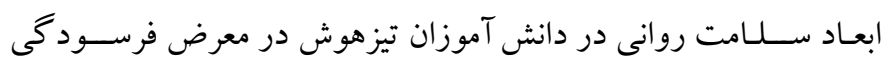
تحصيلى نشان مىدهد كه اثرات اصلى درون آزمودنى و گرووه و همجينين

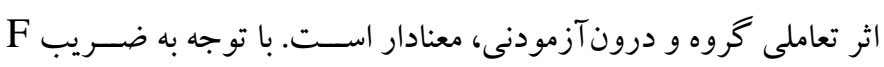




\section{بحث و نتيجه كيرى}

هدف يزٔوهش حاضـر، بررسى اثربخشى برنامه اميدبخشى بر ارتقاى ابعاد

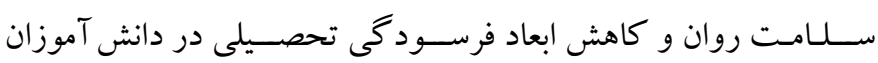
تيزهوش در معرض فرســودگى تحصــيلى بود. نتايج بزؤهش حاضــر با يـافتهـهـاى كريخز (IV)، دانســتن، فالكونر و يرايس (IN) و ناكك (YY)

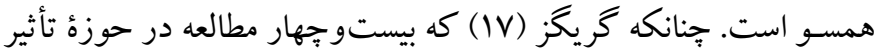
اميد بر سلامت روانى را مورد بررسى قرار داد، در يكك فرا تحليل بيشنهاد داد كـه اميـددرمـانى با بهبود مهارت هاى مقابلهاى و بهزيسـتى روانى در ارتباط اسـت و عامل حفاظتى در ارتكاب به خود كشى محسوب مىشود و در مبـادرت بـه رفتارهاى ســالم از منظر روانى، مؤثر اســت. همجنين دانســتن و همكاران (1) در ئزوهش خود به بررسـى ارتباط ميان اميد، مشــار كـت اجتمـاعى، و بهزيســتى روانى در افراد بـا مشـكلكلات روانى يرداختند و بدين نتيجه رســيدند كه اميد و مشــار كت اجتماعى مىتو اند بهزيســى و ســلـامت روانى را بيش بينى كند. ناكك (Yr) نيز بدين نتيجه رسيد كه اميد عامل مهمى در سلامت روان افر اد مبتلا به سوءمصرف الكل محسوب مىشود. از نظر ناكك (YY) اميد موجب كاهش ميزان تنيدكى در

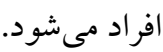

از مجموع نتايج بهدست آمده مى توان جنين استنباط كرد كه آموزش برنامهُ اميدبخشىى به شـيوهُ شـناختى -رفتارى در ابعاد سـلامت روانى (جز خردهمقياس نشـانهاى افسردگگى) و فرسـودگى تحصسيلى دانش آموزان تيزهوش دبيرسـتانى مؤثر بوده اسـت و به آنها در ارتقاى سـلامت روانى

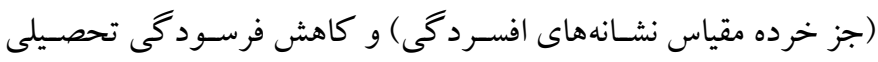
كمكك كرده است. در برنامهٔ مورد استفاده در بزّوهش، بر روى داستانها و حكايات زندكى اعضاى گرووه تمرين شد و به در نتيجه مؤلفههاى اميد، اهداف، گذر گاهها، و نيروى عامل در داستانها و روايات افراد مشخص شد. يس از آن اهداف هر كدام از افراد شناسايى شد و به آنها خصوصيات اهداف مناسـب كفته شـد. در كام بعدى، از آنها خواسـته شـد تا اهداف مهم و قابل دسـيابى خود را اولويتبندى كرده و راههاى رسـيدن به اين اهداف را مشخص كنند. يكى از بنيادى ترين بخش در اين برنامه، تقويت تفكر مثبت و مثبتانديشـى بود و در مقابل، تلاش شـد تا خود گويىهاى منفى در اين افراد از ميان برداشته شود.

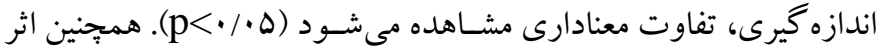
بين گروهى نشــان مى دهد بين ميانگين هاى علائم جســمانى، نشــانهاى اضــطراب، و كار كرد اجتماعى شــركت كنند كان برحســبـ عضــويت

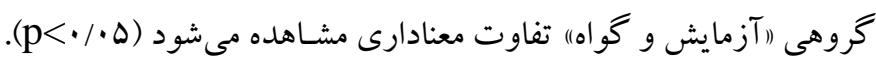
همجِنين معنـادارى اثر تعـاملى نشــان مىدهل بين تفاوت نمرات افراد در زمـانهـاى مختلف در گروه آزمـايش و گو اه نيز تفـاوت معنـادار وجود دارد؛ بنابر اين با توجه به ميانخين هاى مشــاهدهـــده در بخش توصـــى نتيجه گرفته مىشـود كه فرض صسفر رد شده و آموزش برنامهُ اميدبخشى در شر كت كنند گان گرووه آزمايشى نسبت به گروه گواه، تأثير بيشترى بر علائم جسمانى، نشانهاى اضطراب، و كار كرد اجتماعى در دانش آموزان در معرض فرسودكى تحصيلى داشته است. همجينين نتايج تحليل دادهها درباره تأثير آموزش برنامهُ اميدبخشى بر كاهش ابعـاد فرســودگى تحصــيلى در دانش آموزان تيزهوش، نشــان مى دهد، اثرات اصسلى درون آزمودنى و گرووه و همجنين اثر تعاملى كروه و درونآزمودنى، معنادار اسـت. با توجه به ضـريب F محاسـبه شــده اثر

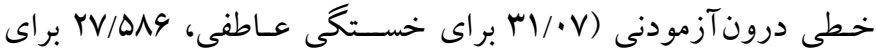

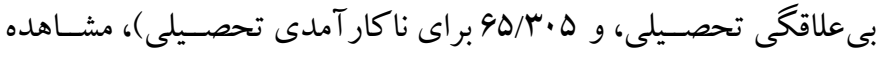

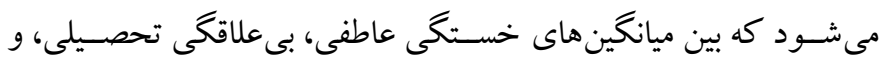
ناكار آمدى تحصيلى در سه مرحله اندازه گيرى، تفاوت معنادارى مشاهده

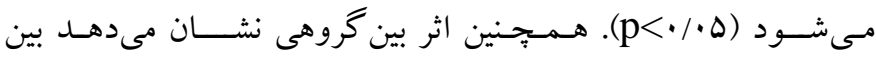
ميـانگين هـاى خســــى عـاطفى، بـىعلـاقكى تحصــيلى، و نـاكار آمدى تحصسيلى شـركت كنند كان برحسب عضويت گروهى ("آزمايش و گو اه)) تفـاوت معنادارى مشــاهده مىشـــود (ه •/p). همجِنين معنادارى اثر تعـاملى نشــان مىدهـد بين تفاوت نمرات افراد در زمانهاى مختلف در كروه آزمـايش و گو اه نيز تفـاوت معنادار وجود دارد؛ بنابراين با توجه به ميانگينهاى مشــاهدهــده در بخش توصـيفى نتيجه كرفته مىشـود كه فرض صــفر رد شــده و برنامهٔ اميدبخشـى در شــر كت كنند كان كروه

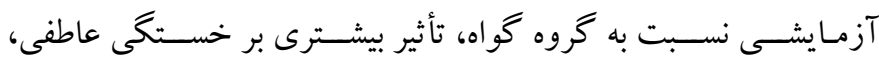
بى علاقكى تحصـيلى، و ناكار آمدى تحصـيلى در دانش آموزان تيزهوش در معرض فرسودگى تحصيلى داشته است. 


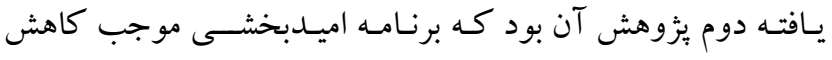

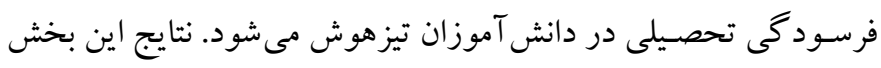

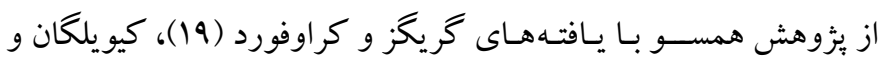

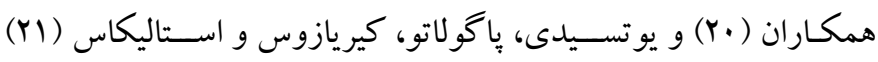

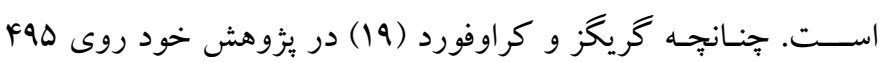
دانشـجو، بدين نتيجه رسـيدند كه اميد نقش مهمى را در بهبود بيشـرفت

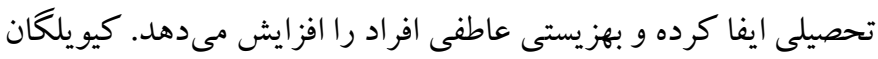

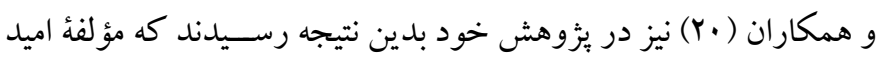

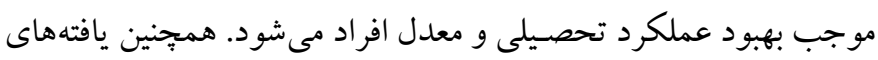

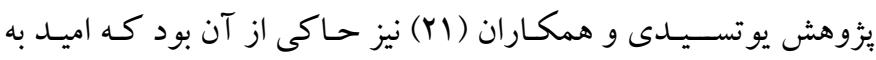
طور كلى نقش مثبتى در عملكرد تحصــيلى و شــلى ايفا مى كند و اميد

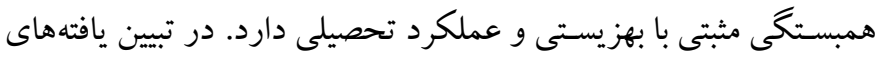

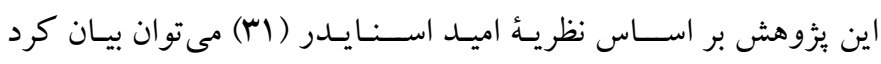

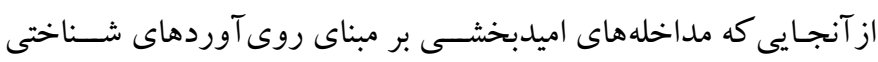
رفتارى طراحى شدهاند، مؤثر بودن اين مداخلهها دور از انتظار نيست. در

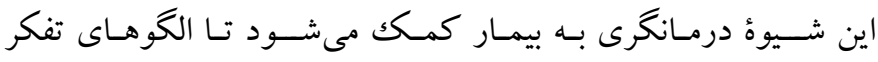

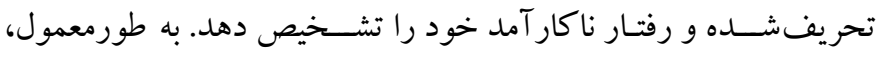

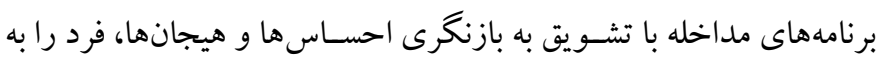

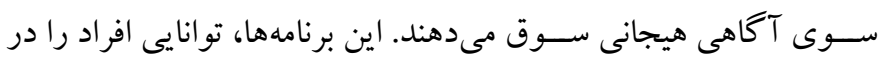

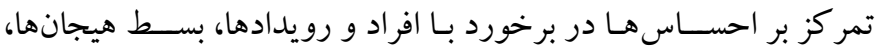

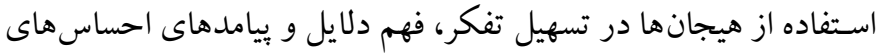
خود و توانـايى فهم ارتباط بين هيجـانها و تفسـير آنها، بهبود مىدهند.

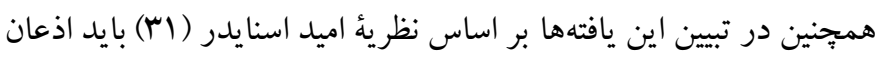

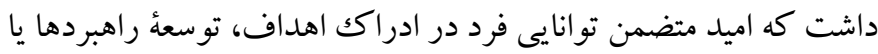

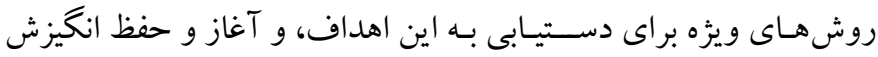

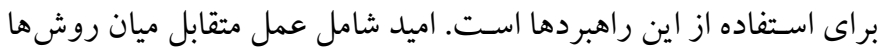

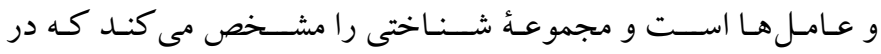

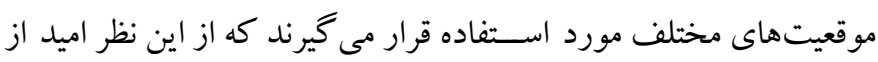

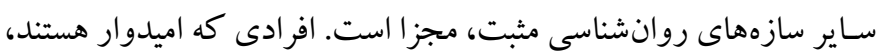

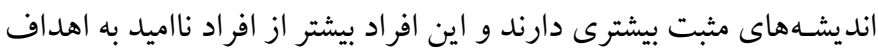
خود دست مى يابند (19).
نتـايج بـهدسـت آمده در اين مطالعه را مىتوان بر اســاس نظريه اميد

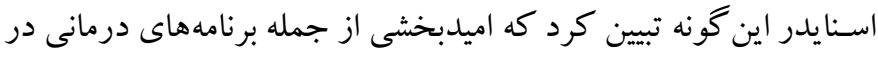

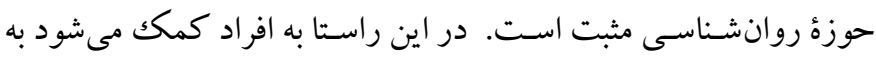

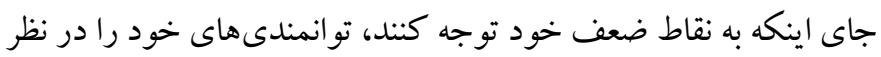
داشته باشند. افر ادى كه اميد بالايى داشته باشند، مى توانند از خود در برابر مشكلات روانى عديدهاى كه سلامت جامعه را به خطر مى اندازد، همجيون اضطر اب، مشكلات خواب، و نشانگًان بدنى، محافظت كنند. اين دسته از

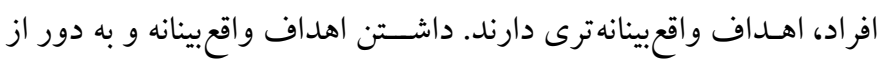
اغراق و مبـالغه، موجب مىشــود كه افر اد به توانمندى هاى خود بيشــتر

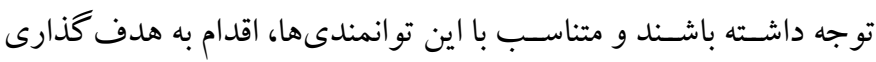

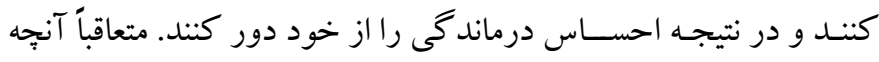

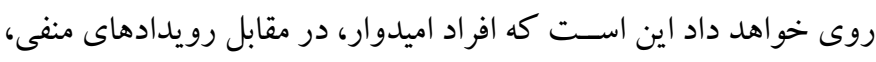

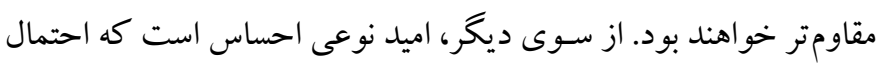

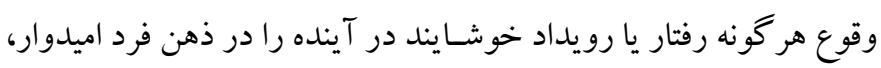

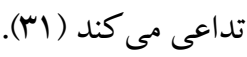

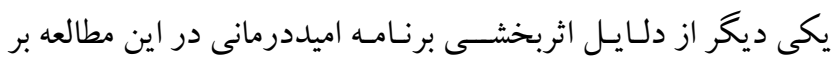

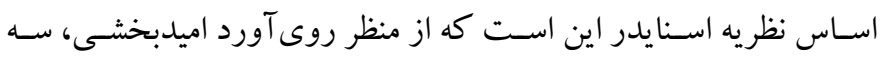

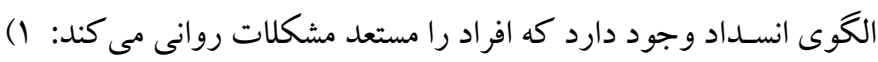

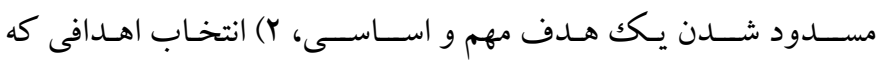

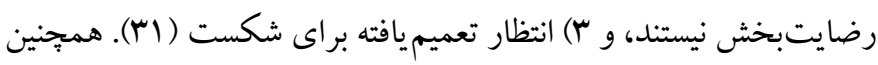
از منظر اميدبخشـى، از دسـت رفتن عامل با انســـاد هدف و ناتوانى در

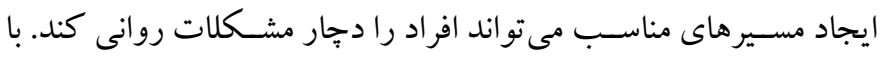
توجه به اهميت انسـداد اهداف در بروز مشـكلات روانى، در اميدبخشى لهـ

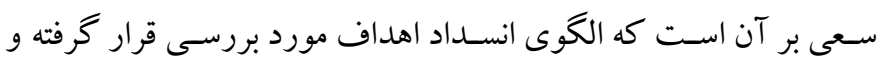

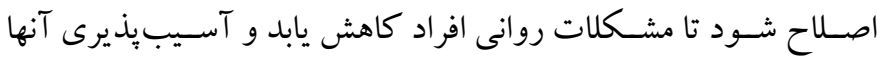

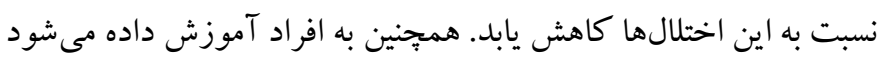

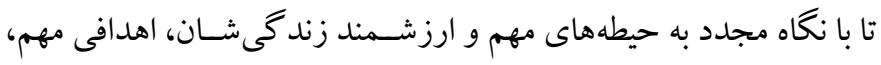

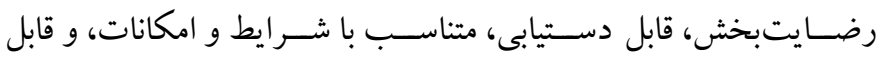

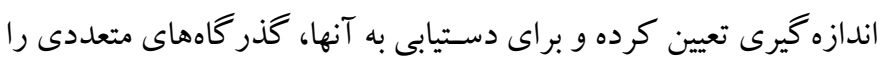

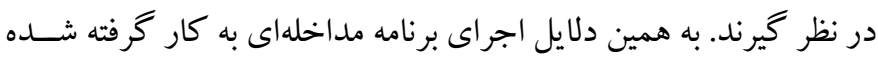

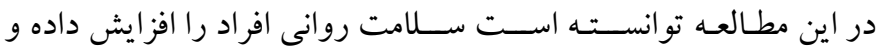
فرسودگى آنان را كاهش دهد. 
افر اد را در بر ابر هيجـانهـاى منفى و عوامـل خطرســـاز مانند رويدادهاى

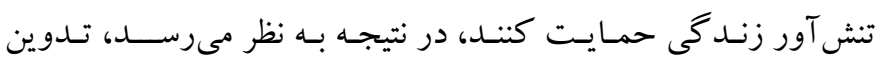

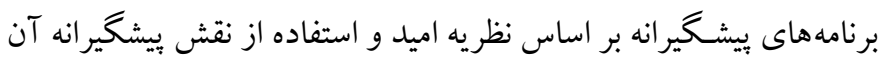
براى دانش آموزان و نوجوانان، مفيد باشد. بهان.

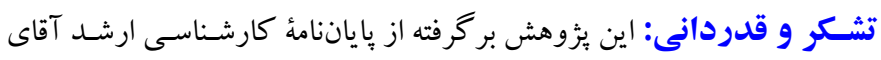

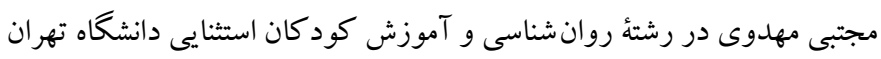

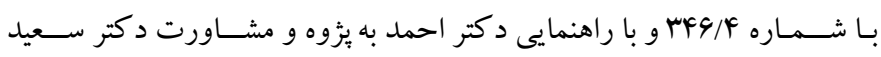

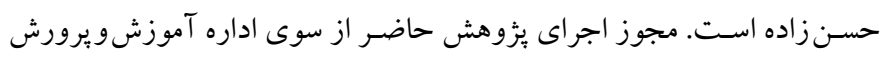

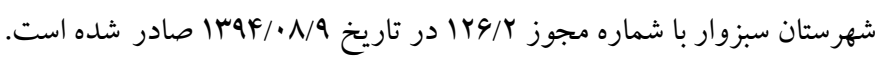

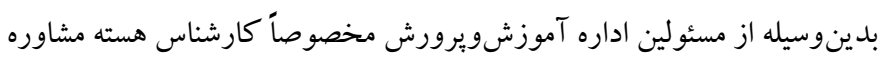

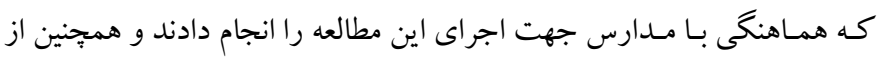

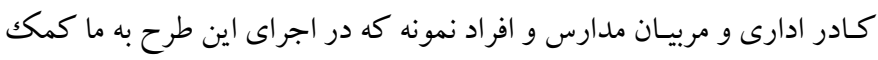

$$
\text { كردند، تشكر و قدردانى مى شود. }
$$

تضـاد منافع: نويسند گان اين مطالعه هيج گَونه تضاد منافع را گزارش نكردند.

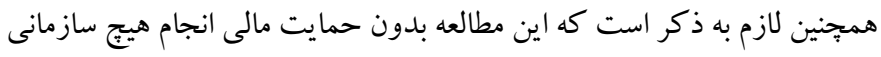
انجام شــه اسـت و تمامى يافتههاى يثزوهش به طور دقيق و شـفاف بيان شـــه
يثزوهش حاضسر نيز همانند سـاير يثزوهشها با محدوديتهايى مو اجه

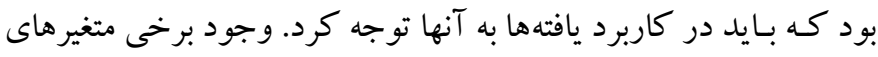

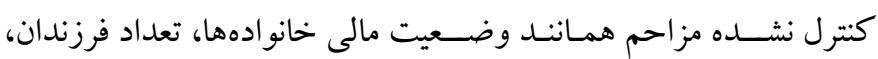

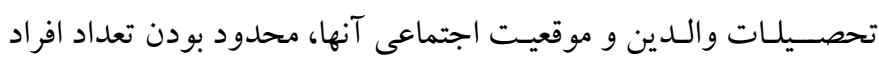

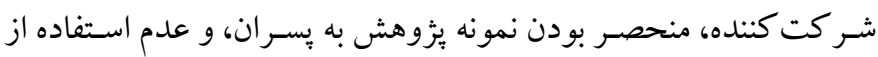

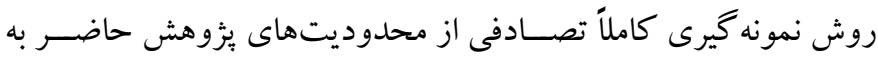

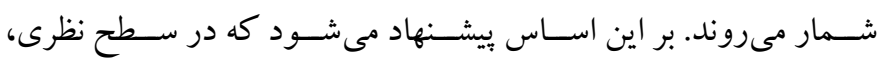

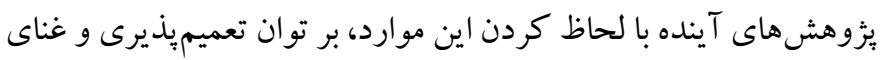

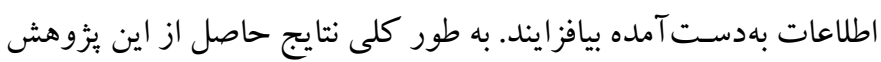

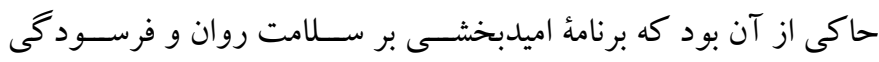
تحصيلى دانش آموزان تيزهوش مؤثر است. بر اين اساس بيشنهاد مى بـود برد

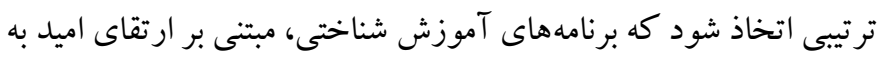

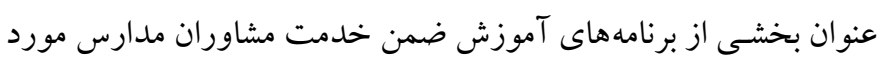

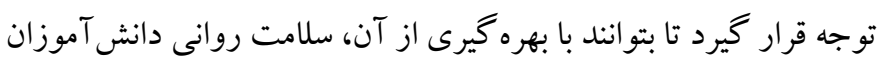

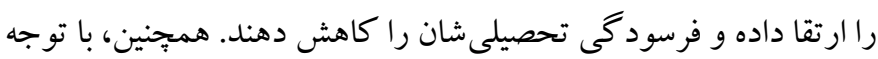

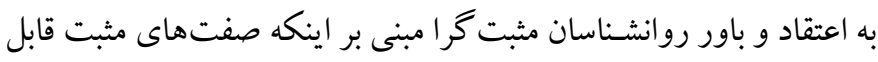

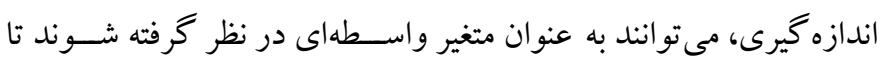




\section{References}

1. Nada CI, Santos SA, Macedo E, Araújo HC. Can mainstream and alternative education learn from each other? An analysis of measures against school dropout and early school leaving in Portugal. Educational Review. 2020; 72(3): 365-385. [Link]

2. Heward WL, Alber-Morgan SR, Konrad M. Exceptional children: An introduction to special education. 11th edition. Upper Saddle River: Pearson; 2018, pp: 33-34. [Link]

3. Worrell FC, Subotnik RF, Olszewski-Kubilius P, Dixson DD. Gifted students. Annu Rev Psychol. 2019; 70: 551-576. [Link]

4. Reis SM, Renzulli JS. Identification of students for gifted and talented programs. 1 edition. Thousand Oaks, Calif: Corwin; 2004, pp: 11-12. [Link]

5. Sternberg RJ. Explorations in giftedness. 1 edition. Cambridge ; New York: Cambridge University Press; 2010, pp: 111-112. [Link]

6. National Association for Gifted Children. What is giftedness? [Internet]. [cited 2020 Feb 3]. Available from: [Link]

7. Martin LT, Burns RM, Schonlau M. Mental disorders among gifted and nongifted youth: A selected review of the epidemiologic literature. Gift Child Q. 2010; 54(1): 31-41. [Link]

8. Lai J, Ma S, Wang Y, Cai Z, Hu J, Wei N, et al. Factors associated with mental health outcomes among health care workers exposed to coronavirus disease 2019. JAMA Netw Open. 2020; 3(3): e203976. [Link]

9. Stone L, Waldron R. Great expectations and e-mental health: The role of literacy in mediating access to mental healthcare. Aust J Gen Pract. 2019; 48(7): 474479. [Link]

10. Organization WH. Mental health: A state of wellbeing [Internet]. [cited 2020 Feb 3]. Available from: [Link]

11. Terman LM, Oden MH. The gifted child grows up: Twenty-five years' follow-up of a superior group. Stanford Univ Press; 1947, pp: 22-23. [Link]

12. Montgomery D. Able underachievers. London: Whurr; 2000, pp: 33-35. [Link]

13. Peters WA, Grager-Loidl H, Supplee P. Underachievement in gifted children and adolescents: Theory and practice. In: Heller KA, Monks FJ, Subotnik R, Sternberg R, editor. International handbook of giftedness and talent. Amsterdam: Elsevier; 2002, pp: 609-620. [Link]

14. Salmela-Aro K, Savolainen H, Holopainen L. Depressive symptoms and school burnout during adolescence: evidence from two cross-lagged longitudinal studies. J Youth Adolesc. 2009; 38(10): 1316-1327. [Link]

15. Segal ZV, Anderson AK, Gulamani T, Dinh Williams L-A, Desormeau P, Ferguson A, et al. Practice of therapy acquired regulatory skills and depressive relapse/recurrence prophylaxis following cognitive therapy or mindfulness based cognitive therapy. J Consult Clin Psychol. 2019; 87(2): 161-170. [Link]

16. Snyder CR, Shorey HS, Cheavens J, Pulvers KM, Adams III VH, Wiklund C. Hope and academic success in college. J Educ Psychol. 2002; 94(4): 820 826. [Link]

17. Griggs S. Hope and mental health in young adult college students: An integrative review. J Psychosoc Nurs Ment Health Serv. 2017; 55(2): 28-35. [Link]

18. Dunstan DA, Falconer AK, Price IR. The relationship between hope, social inclusion, and mental wellbeing in supported employment. The Australian Journal of Rehabilitation Counselling. 2017; 23(1): 37-51. [Link]

19. Griggs S, Crawford SL. Hope, core self-evaluations, emotional well-being, health-risk behaviors, and academic performance in university freshmen. J Psychosoc Nurs Ment Health Serv. 2017; 55(9): 3342. [Link]

20. Kivlighan DM, Abbas M, Gloria AM, Aguinaga A, Frank C, Frost ND. Are belongingness and hope essential features of academic enhancement groups? A psychosociocultural perspective. J Couns Psychol. 2018; 65(2): 204-213. [Link]

21. Yotsidi V, Pagoulatou A, Kyriazos T, Stalikas A. The role of hope in academic and work environments: An integrative literature review. Psychology. 2018; 9(3): 385-402. [Link]

22. Wnuk M. Hope as an important factor for mental health in alcohol-dependent subjects attending alcoholics anonymous. Journal of Substance Use. 2017; 22(2): 182-186. [Link]

23. Snyder CR, Rand KL, King EA, Feldman DB, Woodward JT. "False" hope. J Clin Psychol. 2002; 58(9): 1003-1022. [Link]

24. Kashani FL, Vaziri S, Esmaeil Akbari M, Zeinolabedini N, Sanaei H, Jamshidifar Z. The effectiveness of creating hope on distress of women with breast cancer. Procedia Soc Behav Sci. 2014; 159: 201-205. [Link]

25. Cohen J. Statistical power analysis for the behavioral sciences. 1st Edition. San Diego, CA: Academic Press; 1977, pp: 66-67. [Link] 
26. Goldberg DP, Williams P. A user's guide to the general health questionnaire. Windsor Berks: NFERNelson; 1988, pp: 11-15. [Link]

27. Schaufeli WB, Bakker AB, Hoogduin K, Schaap C, Kladler A. On the clinical validity of the maslach burnout inventory and the burnout measure. Psychol Health. 2001; 16(5): 565-582. [Link]

28. Taghavi SMR. Validity and reliability of the general health questionnaire (ghq-28) in college students of shiraz universi1y. Journal of Psychology. 2002; 5(4): 381-398. [Persian]. [Link]
29. Rostami Z, Abedi MR, Schuffli VB. Standardization of maslash burnout inventory among female students at university of Isfahan. New Educational Approaches. 2011; 6(1): 21-38. [Persian]. [Link]

30. Carr A. Positive psychology: the science of happiness and human strengths. 2 edition. London; New York: Routledge; 2011, pp: 44-45. [Link]

31. Snyder CR. Handbook of hope: theory, measures, and applications. 1 edition. San Diego, Calif: Academic Press; 2000, pp: 33-34. [Link] 